Sains Malaysiana 50(6)(2021): 1745-1754

http://doi.org/10.17576/jsm-2021-5006-20

\title{
The Effects of Apitherapeutic Agents on Oxidative Stress in Serum Metabolic Parameters of Hypertensive Rats Created by Nitric Oxide Synthase Inhibited
}

(Kesan Agen Apiterapeutik terhadap Tegasan Oksidaan dalam Parameter Metabolisme Serum Tikus Hipertensi dihasilkan oleh Sintase Terencat Oksida Nitrik)

\author{
Mehmet Fuat Gulhan, Betul Ozdemir*, Zeliha Selamoglu \& Engin Sahna
}

\begin{abstract}
Hypertension is a chronic disease affecting the whole world due to its clinical effects and complications. The reduction in the release and effect of NO is one of the mechanisms of hypertension formation. Hypertension disrupts the balance between oxidant and antioxidant mechanisms. In this study, we aimed to observe biochemical changes in the blood by treatment propolis, caffeic acid phenethyl ester (CAPE) and pollen in hypertensive rats via N $\omega$-Nitro-L-arginine methyl ester (L-NAME). Rats were divided in five groups. Rats were given L-NAME (40 mg/kg, intraperitoneally) for 14 days to make hypertensive. L-NAME and bee products were administered together with rats for 14 days, then L-NAME for 14 days. All administrated ended 28 days. There was a statistically significant $(P<0.05)$ decrease in blood pressure $(B P)$ in the groups in which bee products were applied. Blood pressure was lower in the pollen treated group than in the $C A P E$ and propolis treated group $(P<0.05)$. Paraoxanase $(P O N 1)$, total antioxidant status $(T A S)$, total oxidant status (TOS), asymmetric dimethylarginine (ADMA), nuclear factor- $\kappa B(N F-\kappa B)$ levels were measured in the blood samples in all groups. In the L-NAME group; PON1, TAS, HDL, and total protein levels were found to be lower than the groups applied bee products $(P<0.05)$. TOS, oxidative stress index (OSI), ADMA, NF- $\kappa B$, glucose, cholesterol, LDL, triglyceride, $A L T, A S T, A L P$ levels were found to be lower in groups plus of bee products were applied compared to the group that received L-NAME $(P<0.05)$. The results showed that oxidative stress and homeostasis can be regulated with propolis, $C A P E$ and pollen in hypertensive rats induced L-NAME.
\end{abstract}

Keywords: Asymmetric dimethylarginine; bee products; blood; nuclear factor- $\kappa$; oxidative stress; paraoxanase; rat

ABSTRAK

Hipertensi adalah penyakit kronik yang menyerang seluruh dunia kerana kesan dan komplikasi klinikalnya. Pengurangan pembebasan dan kesan NO adalah salah satu mekanisme pembentukan hipertensi. Hipertensi mengganggu keseimbangan antara mekanisme oksidan dan antioksidan. Tujuan kajian ini adalah untuk memerhatikan perubahan biokimia dalam darah dengan propolis rawatan, asid fenil ester kafeik (CAPE) dan debunga pada tikus hipertensi melalui

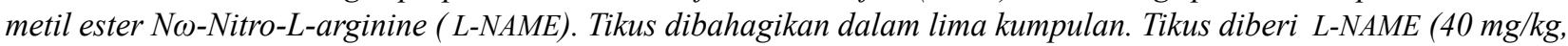
intraperitoneal) selama 14 hari untuk membuat hipertensi. L-NAME dan produk lebah diberikan bersama tikus selama 14 hari, kemudian L-NAME selama 14 hari. Semua pemberian berakhir pada 28 hari. Terdapat penurunan tekanan darah $(P<0.05)$ yang signifikan secara statistik pada kelompok yang menggunakan produk lebah. Tekanan darah lebih rendah pada kumpulan yang dirawat debunga daripada kumpulan yang dirawat CAPE dan propolis $(P<0.05)$. Paraoksanase (PON1), status antioksidan total (TAS), status oksidan total (TOS), dimetilarginin asimetrik (ADMA), tahap faktor nuklear- $\kappa B(N F-\kappa B)$ diukur dalam sampel darah dalam semua kumpulan. Dalam kumpulan L-NAME; Tahap protein PON1, TAS, HDL dan jumlah protein didapati lebih rendah daripada kumpulan produk lebah yang digunakan ( $P$ <0.05). TOS, indeks tekanan oksidatif (OSI), ADMA, NF- $\kappa B$, glukosa, kolesterol, LDL, trigliserida, ALT, AST, kadar ALP didapati lebih rendah dalam kumpulan ditambah produk lebah digunakan berbanding dengan kumpulan yang menerima L-NAME $(P<0.05)$. Hasil kajian menunjukkan bahawa tekanan oksidatif dan homeostasis dapat diatur dengan propolis, CAPE dan debunga pada tikus hipertensi yang disebabkan L-NAME.

Kata kunci: Darah; dimetilarginina tak simetri; faktor nuklear- $\kappa B$; paraoksanase; produk lebah; tegasan oksidaan; tikus 


\section{INTRODUCTION}

Hypertension is a chronic disease affecting the whole world due to its clinical effects and complications (Ferrannini \& Cushman 2012). Therefore, early diagnosis and treatment of hypertension is important. The nitric oxide synthesized by the vascular endothelium regulates blood pressure (Palmer et al. 1987). Nitric oxide synthase (NOS) provides nitric oxide (NO) synthesis. The reason for the occurrence of hypertension is the increase in vascular tonus caused by inhibition of the enzyme. Nitric oxide passes through the endothelium and shows its effect in the interstitial space (Harrison et al. 2007). NO has the task of adjusting vascular tone with vasodilation effect. The reduction in the release and effect of NO is one of the mechanisms of hypertension formation. Hypertension disrupts the balance between oxidant and antioxidant mechanisms (Talas 2014). Biochemical parameters in the blood can give information about the health status of living things. Changes in endogenous NOS inhibitor levels cause changes in ADMA level. Plasma ADMA concentration increases in hypertensive patients (Taner et al. 2013). The decreasing in reactive oxygen species (ROS) levels is perceived as a physiological warning. It stimulates signal transduction, apoptosis, and gene expression and activates transcription factors such as nuclear factor- $\kappa \mathrm{B}$ $(\mathrm{NF}-\kappa \mathrm{B})$. Transcription factors such as NF- $\mathrm{KB}$ are affected by low ROS levels. The stimuli that activate NF- $\kappa$ B can be inhibited by enzymatic and non-enzymatic antioxidant molecules (Celec 2004). NF- $\mathrm{BB}$ regulates inducible nitric oxide synthase (iNOS) (Xu et al. 1998). Various functional dietary supplements are recommended for the treatment of hypertension diseases. Preference of natural products in folk medicine has increased due to its low toxicity and therapeutic properties (Ryu et al. 2008). Natural products have been antihypertensive effects such as some flavonoids and polyphenols have antihypertensive properties due to their vasodilating and hypotensive effects (Ashraf et al. 2013; Gogebakan et al. 2012; Maruyama et al. 2009). Apitherapeutic agents like propolis, polen, and CAPE (caffeic acid phenethyl ester) whole are named bee products. Propolis is one of the natural products frequently used in folk medicine (Mishima et al. 2005). Propolis has antibacterial, antiviral, anti-inflammatory and anticancer and antihypertensive effects (Prytzyk et al. 2003; Talas \& Gulhan 2009). CAPE is one of the basic structures of propolis (Bankova 2009). It is frequently used in research because it reduces oxidative stress (Atik et al.
2006; Ogeturk et al. 2005; Okutan et al. 2005). Pollen is collected from many plants by the honey bee. Pollen is a powerful antioxidant and is a polyphenolic compound (Mărghitas et al. 2009; Selamoglu et al. 2015; Talas et al. 2014). Oxidation of low-density lipoprotein (LDL) is associated with oxidative stress and oxidized LDL causes atherosclerosis. It protects against atherosclerosis due to its high-density lipoprotein (HDL) antioxidant (Azarsiz et al. 2003). PON1 is an HDL-bound enzyme system and hydrolyzes active phospholipids and lipid peroxide products, thereby preventing oxidation of LDL and HDL (Rozenberg et al. 2008). Previous studies have shown the serum PON1 activities decreased in atherosclerotic diseases, myocardial infarction, slow coronary flow, cardiac syndrome, hypercholesterolemia, and diabetes (González et al. 2019; Mackness \& Mackness 2015; Pérez-Méndez et al. 2014). The antioxidants rich in flavonoids might be cause a $20 \%$ increasing in PON1 activity in the serum (Salmas et al. 2017). Studies have shown that endothelial functions depend on serum PON1 activity so that the coronary tone is regulated. Coronary artery disease has been associated with these effects (Granér et al. 2006; Gur et al. 2006; Pasqualini et al. 2005). The aim of this study was to investigate patch the variability of TAS, TOS, OSI, ADMA, NF- $\kappa$ B levels, PON1 activities, and routine biochemical parameters in serum of hypertensive rats treated with bee products.

\section{MATERIALS AND Methods}

\section{CHEMICALS}

In this study, $\mathrm{N}(\omega)$-nitro-L-arginine methyl ester (Cayman Chemical Company, Michigan, USA) used to make rats hypertensive. PON1 assay kit (MEGA TIP San. Tic. Ltd. Sti. Gaziantep, Turkey); TAS and TOS assay kits (MEGA TIP San. Tic. Ltd. Sti. Gaziantep, Turkey); NF-кB kit (Hangzhou Eastbiopharm Co., Ltd, Zhejiang, China) were used for measuring the biochemical parameters.

\section{PREPARATION OF PROPOLIS EXTRACTIVE SOLUTION}

Propolis was divided into small pieces and extracted with ethanol. After that, it was centrifuged and dried (Talas \& Gulhan 2009).

\section{PREPARATION OF POLLEN EXTRACTIVE SOLUTION}

Bee pollen was extracted three times with ethanol. After extraction it was filtered and dried (Marghitas et al. 2009). 


\section{ANIMALS}

28 male spraque dawley rats were used for this study. Firat University Animal Research Committee approved the study.

\section{EXPERIMENTAL PROCEDURE}

Spraque dawley rats were divided into five groups. Groups are Control, L-NAME, L-NAME+propolis, L-NAME+pollen, and L-NAME+CAPE. Normal saline was applied to the control group for 28 days. L-NAME group was given L-NAME for 28 days. The L-NAME group was given non-specific NOS inhibitor L-NAME $(40 \mathrm{mg} / \mathrm{kg}$; i.p.) for 28 days (Nguelefack et al. 2009). The other 3 groups were given L-NAME only for the first 14 days, and L-NAME and bee products together for the next 14 days. The L-NAME+ propolis group was given bothL-NAME (40 $\mathrm{mg} / \mathrm{kg}$; i.p.) for 28 days and propolis $(200 \mathrm{mg} / \mathrm{kg} / \mathrm{d}$; by gavage) (Kolankaya et al. 2002). CAPE (Sigma-Aldrich; $50 \mu \mathrm{M} / \mathrm{kg} / \mathrm{d}$; i.p.) and pollen $(100 \mathrm{mg} / \mathrm{kg} / \mathrm{d}$; by gavage $)$ were administered on the last 14 of 28 days (Kanbur et al. 2009; Parlakpinar et al. 2005). The animals were sacrificed after being anesthetized with $75 \mathrm{mg} / \mathrm{kg}$ of sodium pentobarbital after the treatments and then $4 \mathrm{~mL}$ blood was taken from the anesthetized rats by entering into the right ventricle their hearts. The bloods were centrifuged in $3000 \mathrm{~g}$ at $4{ }^{\circ} \mathrm{C}$ for $5 \mathrm{~min}$.

\section{BIOCHEMICAL ASSAYS IN THE BLOOD SERUM}

After the centrifuged; glucose, cholesterol, high density lipoprotein (HDL), low density lipoprotein (LDL), triglyceride, aspartate aminotransferase (AST), alanine aminotransferase (ALT), alkaline phosphatase (ALP) levels in the blood serum of the rats were measured by autoanalyzer.

\section{BLOOD PRESSURE MEASUREMENT}

Tail cuff method (MAY BPHR 9610-PC Tail-Cuff Indirect Blood Pressure Recorder Commat Ltd., Ankara, Turkey) used for BP measuring (Simko et al. 2004). The lowest three values were used for the average blood pressure.

\section{DETERMINATION OF PON1 ACTIVITY}

In the absence of basal activity, PON1 activity was measured and U/L expressed (Eckerson et al. 1983).

\section{MEASUREMENT OF THE TOTAL ANTIOXIDANT STATUS}

TAS level was measured with an automatic measurement method (Erel 2004). The antioxidative effect of the sample was measured with the produced hydroxyl radical and expressed as mmol Trolox Equivalent/L.

\section{MEASUREMENT OF THE TOTAL OXIDANT STATUS}

TOS level was measured with a new automatic measurement method developed by Erel (2005) and expressed in micromolar hydrogen peroxide $\left(\mu \mathrm{mol} \mathrm{H}_{2} \mathrm{O}_{2}\right.$ equiv./L) per liter.

\section{OXIDATIVE STRESS INDEX}

OSI level was calculated by proportioning TOS level to TAS level. The resulting TAS unit was changed to mmol/L (Kosecik et al. 2005).

\section{DETERMINATION OF ADMA LEVELS}

ADMA level was measured with ADMA ELISA kit (Hangzhou EASTBIOPHARM CO., LTD). The color changes from blue to yellow and the absorbance is measured at $450 \mathrm{~nm}$ on the photometer (Horowitz \& Hersztyn 2007).

\section{DETERMINATION OF NF-KB LEVELS}

$\mathrm{NF}-\kappa \mathrm{B}$ activity measured by a colorimetric assay. The absorbance of the samples using a spectrophotometric reader at $450 \mathrm{~nm}$ (Al-Maghrebi et al. 2009).

\section{STATISTICAL ANALYSIS}

Biochemical data were tested with SPSS 21.0. One-way analysis of variance (ANOVA) was used. The differences between the averages were determined by the Tukey test $(\mathrm{P}<0.05)$.

\section{RESULTS}

Tail-cuff method was used for measuring blood pressure (BP). L-NAME was applied for 28 days to create hypertension. Bee products were applied to some groups after 14 days. There was no significant change in all experimental groups $(\mathrm{P}>0.05)$ on day 0 in $\mathrm{BP}$ (Table 1). After applying L-NAME for 14 days, rats in all experimental groups $(\mathrm{P}<0.05)$ increased significantly compared to control rats (Table 1). 
TABLE 1. Changes in blood pressure at 0th, 14th and 28th days

\begin{tabular}{|c|c|c|c|c|c|c|}
\hline \multirow{2}{*}{$\begin{array}{c}\text { DAYS } \\
\text { (MMHG) }\end{array}$} & \multicolumn{6}{|c|}{ Experimental groups } \\
\hline & $\begin{array}{l}\text { Group I } \\
\text { (Control) }\end{array}$ & $\begin{array}{c}\text { Group II } \\
\text { (L-NAME) }\end{array}$ & $\begin{array}{c}\text { Group III } \\
\text { (L-NAME+Propolis) }\end{array}$ & $\begin{array}{c}\text { Group IV } \\
\text { (L-NAME+CAPE) }\end{array}$ & $\begin{array}{c}\text { Group V } \\
\text { (L-NAME+Pollen) }\end{array}$ & P-value \\
\hline $0^{\text {th }}$ day & $103.71 \pm 3.56$ & $104.75 \pm 1.69$ & $106.02 \pm 1.99$ & $104.29 \pm 1.82$ & $104.29 \pm 1.12$ & $<0.003$ \\
\hline $14^{\text {th }}$ day & $104.75 \pm 1.69$ & $141 \pm 1.21$ & $141.11 \pm 0.53$ & $143.3 \pm 0.56$ & $143.97 \pm 0.53$ & 0.84 \\
\hline $28^{\text {th }}$ day & $104.29 \pm 1.82$ & $154.56 \pm 1.59$ & $122.7 \pm 1.67$ & $129.29 \pm 0.97$ & $111.13 \pm 1.68$ & 0.27 \\
\hline
\end{tabular}

at 28th days after antioxidant supplementation (propolis, CAPE and pollen administration). All data points are the average of $n=7$ with \pm STDEVs

The systolic blood pressure data of the control, L-NAME, propolis, L-NAME+propolis, L-NAME+CAPE and L-NAME+ pollen groups on the 28th day are given in Table 2. The L-NAME group showed a significant increase in SBP on the 28th day compared to the control group $(\mathrm{P}<0.05)$ (Table 2$)$. In bee products groups were compared to the L-NAME group, there was a significant decrease in SBP $(\mathrm{P}<0.05)($ Table 2$)$. In the pollen group, there was a more significant decrease in SBP than in the propolis and CAPE groups $(\mathrm{P}<0.05)$ (Table 2$)$. Biochemical changes occurring with bee products in rats hypertensive with L-NAME are given in Table 3. A decrease in PON1 activity, TAS, HDL and total protein levels was observed in rats with L-NAME $(\mathrm{P}<0.05)$ (Table 3$)$. There was no difference in PON1 activity and TAS levels in the pollen and CAPE groups compared to the control group $(\mathrm{P}>0.05)$ (Table $3)$. In the propolis group, PON1 and TAS activities were increased compared to the L-NAME group $(\mathrm{P}<0.05)$ (Table $3)$. A decrease in HDL level was observed in the L-NAME group (Table 3 ). HDL levels remained stable in the pollen and CAPE treated groups $(\mathrm{P}>0.05)$, and increased in the propolis treated group $(\mathrm{P}<0.05)$ (Table 3$)$. Total protein level was low in L-NAME group compared to control group (Table 3). Total protein levels increased in groups given bee products $(\mathrm{P}<0.05)$ (Table 3$)$. In the hypertensive group (L-NAME) compared to the control group TOS, OSI, ADMA, NF- $\kappa B$, glucose, cholesterol, LDL, triglyceride, ALT, AST, ALP, urea, creatinine levels were high $(\mathrm{P}<0.05)$ (Table 3). TOS, OSI, LDL, triglyceride, ALT, AST, ALP, creatinine levels were stable in the CAPE and pollen groups $(\mathrm{P}>0.05)$ (Table 4). ADMA level did not change in all groups $(\mathrm{P}>0.05)$ (Table 3$)$. No change in NF- $\kappa B$ was observed in the CAPE group $(\mathrm{P}>0.05)$ (Table 3$)$. The glucose levels did not change in the group of bee products $(\mathrm{P}>0.05)$ (Table 3$)$. In the groups treated propolis, CAPE and pollen as plus to L-NAME administration, there were statistically significant decrease $(\mathrm{P}<0.05)$ in the levels of TOS, OSI, ADMA, NF- $\mathrm{B}$, glucose, cholesterol, LDL, triglyceride, ALT, AST, ALP, urea, creatinine as compared to L-NAME group (Table 3).

TABLE 2. The biochemical changes occurring with the bee products in the serum of hypertensive rats via L-NAME

\begin{tabular}{lccccc}
\hline \multirow{2}{*}{$\begin{array}{c}\text { BIOCHEMICAL } \\
\text { PARAMETERS }\end{array}$} & $\begin{array}{c}\text { Group I } \\
\text { (Control) }\end{array}$ & $\begin{array}{c}\text { Group II } \\
\text { (L-NAME) }\end{array}$ & $\begin{array}{c}\text { Group III } \\
\text { (L-NAME+Propolis) }\end{array}$ & $\begin{array}{c}\text { Group IV } \\
\text { (L-NAME+CAPE) }\end{array}$ & $\begin{array}{c}\text { Group V } \\
\text { (L-NAME+Pollen) }\end{array}$ \\
\hline PON1 (U/L) & $319.29 \pm 16.71$ & $237.14 \pm 12.94$ & $357.71 \pm 10.43$ & $298.71 \pm 23.53$ & $311.43 \pm 37.99$ \\
ADMA (ng/mL) & $3.73 \pm 0.24$ & $5.77 \pm 0.56$ & $3.76 \pm 0.39$ & $4.02 \pm 0.23$ & $3.84 \pm 0.35$ \\
NF-אB(mmol/mL) & $4.35 \pm 0.73$ & $7.0 \pm 0.48$ & $5.27 \pm 0.72$ & $5.20 \pm 0.75$ & $3.32 \pm 0.73$ \\
TAS (mmol/L) & $2.18 \pm 0.03$ & $2.03 \pm 0.05$ & $2.39 \pm 0.04$ & $2.16 \pm 0.05$ & $2.22 \pm 0.02$ \\
TOS $(\mu \mathrm{mol} / \mathrm{L})$ & $12.48 \pm 1.62$ & $20.77 \pm 2.28$ & $9.51 \pm 1.70$ & $11.82 \pm 1.73$ & $13.66 \pm 1.61$ \\
OSI (ratio) & $0.57 \pm 0.07$ & $1.02 \pm 0.130$ & $0.45 \pm 0.14$ & $0.54 \pm 0.08$ & $0.61 \pm 0.07$ \\
\hline
\end{tabular}

All data points are the average of $n=7$ with \pm STDEVs 
TABLE 3. The changes in the routine serum biochemical parameters occurring with bee products in hypertensive rats via L-NAME

\begin{tabular}{|c|c|c|c|c|c|}
\hline \multirow{2}{*}{$\begin{array}{l}\text { BIOCHEMICAL } \\
\text { PARAMETERS }\end{array}$} & \multicolumn{5}{|c|}{ Experimental groups } \\
\hline & $\begin{array}{l}\text { Group I } \\
\text { (Control) }\end{array}$ & $\begin{array}{l}\text { Group II } \\
\text { (L-NAME) }\end{array}$ & $\begin{array}{c}\text { Group III } \\
\text { (L-NAME+Propolis) }\end{array}$ & $\begin{array}{c}\text { Group IV } \\
(\mathrm{L}-\mathrm{NAME}+\mathrm{CAPE})\end{array}$ & $\begin{array}{c}\text { Group V } \\
\text { (L-NAME+Pollen) }\end{array}$ \\
\hline Glucose (mg/dL) & $90.14 \pm 8.98$ & $129.00 \pm 9.66$ & $93.71 \pm 6.92$ & $78.00 \pm 3.36$ & $87.57 \pm 12.02$ \\
\hline $\begin{array}{l}\text { Triglyceride (mg/ } \\
\mathrm{dL})\end{array}$ & $49.85 \pm 11.43$ & $145.00 \pm 10.98$ & $77.57 \pm 7.93$ & $37.85 \pm 6.84$ & $44.42 \pm 7.78$ \\
\hline $\begin{array}{l}\text { Cholesterol (mg/ } \\
\mathrm{dL})\end{array}$ & $44.28 \pm 7.65$ & $59.85 \pm 8.00$ & $53.00 \pm 9.09$ & $37.42 \pm 4.72$ & $52.28 \pm 7.76$ \\
\hline HDL (mg/dL) & $23.85 \pm 4.41$ & $11.00 \pm 2.16$ & $31.00 \pm 4.86$ & $17.57 \pm 3.30$ & $34.71 \pm 1.60$ \\
\hline $\mathrm{LDL}(\mathrm{mg} / \mathrm{dL})$ & $7.85 \pm 1.34$ & $20.00 \pm 2.16$ & $7.85 \pm 1.46$ & $12.00 \pm 1.63$ & $6.85 \pm 1.21$ \\
\hline $\begin{array}{l}\text { Total protein }(\mathrm{g} / \\
\mathrm{dL})\end{array}$ & $6.18 \pm 0.24$ & $4.91 \pm 0.30$ & $6.09 \pm 0.35$ & $5.94 \pm 0.24$ & $6.59 \pm 0.35$ \\
\hline Urea (mg/dL) & $46.28 \pm 1.79$ & $65.28 \pm 1.97$ & $56.14 \pm 2.91$ & $45.57 \pm 5.47$ & $51.42 \pm 5.65$ \\
\hline $\begin{array}{l}\text { Creatinine (mg/ } \\
\mathrm{dL})\end{array}$ & $0.61 \pm 0.03$ & $0.87 \pm 0.07$ & $0.75 \pm 0.08$ & $0.59 \pm 0.06$ & $0.67 \pm 0.03$ \\
\hline
\end{tabular}

All data points are the average of $n=7$ with \pm STDEVs

TABLE 4. The changes occurring with bee products in the serum enzymatic parameters of hypertensive rats via L-NAME

\begin{tabular}{|c|c|c|c|c|c|}
\hline \multirow{2}{*}{ ENZYMATIC } & \multicolumn{5}{|c|}{ Experimental groups } \\
\hline & Group I & Group II & Group III & Group IV & Group V \\
\hline PARAMETERS & (Control) & (L-NAME) & (L-NAME+Propolis) & (L-NAME+CAPE) & (L-NAME+Pollen) \\
\hline AST (U/L) & $258.86 \pm 35.04$ & $467.86 \pm 30.44$ & $230.43 \pm 34.57$ & $346.71 \pm 30.92$ & $242.57 \pm 28.28$ \\
\hline ALT (U/L) & $93.85 \pm 9.65$ & $212.14 \pm 9.24$ & $81.85 \pm 11.09$ & $143.29 \pm 9.89$ & $82.28 \pm 13.45$ \\
\hline $\operatorname{ALP}(\mathrm{U} / \mathrm{L})$ & $454.71 \pm 57.01$ & $626.00 \pm 41.39$ & $377.14 \pm 74.00$ & $510.14 \pm 18.75$ & $380.00 \pm 15.08$ \\
\hline
\end{tabular}

All data points are the average of $n=7$ with \pm STDEVs 


\section{DISCUSSION}

This is one of the first studies to show the relationship between natural bee products (propolis and pollen) and hypertension using markers such as PON1, ADMA, NF$\kappa \mathrm{B}$, TAS, TOS and OSI in the rat blood. The hypotensive effect of propolis, CAPE and pollen has been shown in some previous studies (Gogebakan et al. 2012; Ryu et al. 2008; Talas et al. 2013). There is a highly complex antioxidant system to protect cells and organs against reactive oxygen species. Endogenous and exogenous components are available to neutralize free radicals. Generally, phenolic compounds or polyphenols occur widely in plants. Polyphenels found in all herbal foods act as antioxidants. It is of particular interest to the so-called flavonoids (flavonols, flavones, isoflavones, flavonones, flavanols, and anthocyanins) (Kaliora et al. 2006). Antihypertensive properties of natural products have been shown in some studies (Fernández-Arroyo et al. 2015; Kubota et al. 2004; Maruyama et al. 2009; Sato et al. 2008). Also, natural products such as flavonoids and polyphenols have vasodilating and hypotensive effects (Mishima et al. 2005). Flavonoids display lipid peroxidation, as well as reducing lipid oxidation with the effects of free radical scavenger and metal chelator, as well as showing antihypertensive and antiarthritic effects (Prytzyk et al. 2003). Increased AST, ALT, ALP, and urea levels have been linked to the hypertensive effect of L-NAME. In liver dysfunction and defects in the biosynthesis of these enzymes, the permeability of the liver membrane changes and this enzyme transition to the blood increases. As a result, it is observed that these enzymes are specifically increased in heart and liver injuries (Mohammadzadeh et al. 2007; Prytzyk et al. 2003). In our study, it was observed that the levels of AST, ALT, ALP, and urea with bee products with antioxidant properties decreased compared to the L-NAME group $(\mathrm{P}<0.05)$. A decrease in AST, ALT, ALP, and urea levels was observed in the propolis-treated group. A decrease in AST, ALT, ALP, and urea levels was observed in propolis and pollen groups compared to CAPE group. Consequently, propolis and pollen may prevent L-NAME induced acute tissue damage and serum enzyme profile. L-NAME increased glucose and creatinine levels, this decreased with bee products. An increasing of these parameters is decisive for renal and liver functions. A reduction in these parameters was observed by supplementing natural bee products $(\mathrm{P}<0.05)$. Propolis and pollen reverses hepatic necrosis and kidney tubular damage by improving cellular metabolism. High levels of LDL, cholesterol and triglycerides for coronary artery disease pose a risk and low HDL levels are among the risk factors. Hypertension poses a risk for cardiovascular diseases such as coronary artery disease and stroke.

Hypertension causes changes in lipid profile (Wilma 2011). The results of our study show the effects of natural agents (propolis and pollen) on lipid profiles in hypertensive rats. Phenolic compounds affect lipid metabolism. They also reduce the formation of atherosclerotic plaque over oxidative stress in cases of hyperlipidemia (Anandh Babu et al. 2006). Furthermore, they upregulate hepatic LDL receptor expression (Bogdanski et al. 2012). There is the relationship between arterial blood pressure and blood parameters. Systolic blood pressure and blood lipids have positive correlations in cardiovascular diseases (Cinar et al. 2001). These findings match that of previous works (Anandh Babu et al. 2006; Bogdanski et al. 2012; Talas et al. 2013; Wilma 2011). In our study, hypertension had negative effect on PON1 activity. We have showed that oxidative stress markers were elevated in hypertensive rats. Increased oxidative stress causes increased lipid and protein oxidation. As is known, oxidative stress increase is related in cardiovascular diseases. Oxidative stress also reduces PON1 expression and activity. Studies have found that PON1 activity decreases with oxidative stress. In addition, low serum PON1 activity is present in atherosclerosis (Aslan et al. 2007). One of PON1's duties is the antioxidative activity of HDL. Active lipids in low oxidized LDL are cleaned by PON1, preventing inflammation. In this study, PON1 was associated with both oxidative and lipid profile (Breton et al. 2014).

Therefore, decreased PON1 activity in hypertension has been associated with increased oxidative stress (Selek et al. 2007). Redox changes of sulfhydryl groups with oxidative stress reduce PON1 activity. Oxidized LDL is reduced with PON1 and inflammation in the artery wall is taken under control (Selek et al. 2008). Due to its antioxidant effects, flavonoids cause an increase in PON1 activity in serum (Mackness et al. 2005). In our study, antioxidant agents such as propolis, CAPE and pollen increased PON1 activity and decreased LDL levels. Aviram et al. (1999) demonstrated the interaction of LDL oxidation and PON inactivation. Aviram et al. (1998) showed the relationship between HDL and PON1. Low cGMP levels in animals receiving L-NAME is due to decreased activity of many proteins such as eNOS and sGC (Leo et al. 2015). NO produced by the enzyme NO synthase (NOS) from $\mathrm{L}$-arginine in cells is produced by endothelial NO synthase (eNOS) in endothelial cells (Alpoim et al. 2015). ADMA inhibits eNOS activity. Increased ADMA levels cause 
endothelial dysfunction (Leo et al. 2015). Plasma ADMA levels L-NAME increases the level of ADMA (Palm et al. 2007). In cardiovascular disease, hypertension is one of risk. NO is necessary for blood pressure control, so ADMA is associated with cardiovascular diseases (Alpoim et al. 2015). A decrease in ADMA levels with antioxidants has been shown in some studies (Bayerle-Eder et al. 2002; John et al. 2001; Vasa et al. 2001). In our study, bee products were found to perform immunostimulant function. The current study has shown that propolis has an antagonist effect for L-NAME. Phenolic compounds are found in propolis and pollen structure. Due to its antioxidant effects, it plays an important role in the metabolic responds in the prevention of heart diseases. NF- $\mathrm{BB}$ regulates the expression and transcription factors of adhesion molecules in endothelial cells. NF- $\kappa B$ is activated with an increase in ROS. The links between ROS generation and NF- $\mathrm{BB}$ are not so far fully understood (Madamanchi \& Runge 2013). The mechanism of inhibition of HDL on NF- $\kappa B$ activation can be related to the inhibition of ROS increase (Robbesyn et al. 2004). We shown increasing of NF-kB activation on oxidative stress and hypertention made by L-NAME in the blood serum. It was observed that NF$\kappa \mathrm{B}$ activity increased when there was oxidative damage (Eckerson et al. 1983; Simão et al. 2011; Zheng et al. 2010). $\mathrm{NF}-\kappa \mathrm{B}$ is an oxidative stress response factor. Antioxidants can block activate NF-אB (Xu et al. 1998). Bee products caused decreased NF- $\kappa B$ activity in rats hypertensive with L-NAME. Anti-inflammatory activities of phenolics may be mediated by transcriptional factor NF- $\kappa \mathrm{B}$ in cells (Babu \& Liu 2008). Bee products are known to be potent antioxidants. We suggest that propolis and pollen may be used to protect against hypertensive effects of L-NAME. We also think that these products can be used with antioxidant effects in cardiovascular dysfunction and some metabolic disorders. This study will direct new developments and researches due to the effects of bee products on homeostasis in the organism.

\section{CONCLUSION}

These results showed that oxidative stress regulation can be achieved with bee products in hypertensive rats via L-NAME. In this study, it was seen that oxidative status and serum lipid profile can be regulated with PON1. We also observed that LDL levels and oxidative stress decreased with treatment of bee products. It may be results with atherosclerosis protection and homeostasis.

\section{ACKNOWLEDGEMENTS}

We thank Nigde Ömer Halisdemir University (Turkey) Research Fund (Project number: BAP 2012/38) for supporting this work.

\section{REFERENCES}

Al-Maghrebi, M., Benter, I.F. \& Diz, D.I. 2009. Endogenous angiotensin-(1-7) reduces cardiac ischemia-induced dysfunction in diabetic hypertensive rats. Pharmacological Research 59(4): 263-268.

Alpoim, P.N., Sousa, L.P., Mota, A.P., Rios, D.R. \& Dusse, L.M. 2015. Asymmetric dimethylarginine (ADMA) in cardiovascular and renal disease. Clinica Chimica Acta 440: 36-39.

Anandh Babu, P.V., Sabitha, K.E. \& Shyamaladevi, C.S. 2006. Green tea extract impedes dyslipidaemia and development of cardiac dysfunction in streptozotocindiabetic rats. Clinical and Experimental Pharmacology \& Physiology 33(12): 1184-1189.

Ashraf, R., Khan, R.A., Ashraf, I. \& Qureshi, A.A. 2013. Effects of Allium sativum (garlic) on systolic and diastolic blood pressure in patients with essential hypertension. Pakistan Journal of Pharmaceutical Sciences 26(5): 859-863.

Aslan, M., Kosecik, M., Horoz, M., Selek, S., Celik, H. \& Erel, O. 2007. Assessment of paraoxonase and arylesterase activities in patients with iron deficiency anemia. Atherosclerosis 191(2): 397-402.

Atik, E., Görür, S. \& Kiper, A.N. 2006. The effect of caffeic acid phenethyl ester (CAPE) on histopathological changes in testicular ischemia-reperfusion injury. Pharmacological Research 54(4): 293-297.

Aviram, M., Rosenblat, M., Billecke, S., Erogul, J., Sorenson, R., Bisgaier, C.L., Newton, R.S. \& La Du, B.N. 1999. Human serum paraoxonase (PON 1) is inactivated by oxidized low density lipoprotein and preserved by antioxidants. Free Radical Biology \& Medicine 26(7-8): 892-904.

Aviram, M., Rosenblat, M., Bisgaier, C.L., Newton, R.S., PrimoParmo, S.L. \& La Du, B.N. 1998. Paraoxonase inhibits high-density lipoprotein oxidation and preserves its functions. A possible peroxidative role for paraoxonase. The Journal of Clinical Ivestigation 101(8): 1581-1590.

Azarsiz, E., Kayikcioglu, M., Payzin, S. \& Yildirim Sözmen, E. 2003. PON1 activities and oxidative markers of LDL in patients with angiographically proven coronary artery disease. International Journal of Cardiology 91(1): 43-51.

Babu, P.V. \& Liu, D. 2008. Green tea catechins and cardiovascular health: An update. Current Medicinal Chemistry 15(18): 1840-1850.

Bankova, V. 2009. Chemical diversity of propolis makes it a valuable source of new biologically active compounds. Journal of ApiProduct and ApiMedical Science 1: 23-28. 
Bayerle-Eder, M., Fuchsjäger-Mayrl, G., Sieder, A., Polska, E., Roden, M., Stulnig, T., Bischof, M.G., Waldhäusl, W., Schmetterer, L. \& Wolzt, M. 2002. Effect of pravastatin on responsiveness to $\mathrm{N}$-monomethyl-L-arginine in patients with hypercholesterolaemia. Atherosclerosis 160(1): 177184.

Bogdanski, P., Suliburska, J., Szulinska, M., Stepien, M., PupekMusialik, D. \& Jablecka, A. 2012. Green tea extract reduces blood pressure, inflammatory biomarkers, and oxidative stress and improves parameters associated with insulin resistance in obese, hypertensive patients. Nutrition Research 32(6): 421-427.

Breton, C.V., Yin, F., Wang, X., Avol, E., Gilliland, F.D. \& Araujo, J.A. 2014. HDL anti-oxidant function associates with LDL level in young adults. Atherosclerosis 232(1): 165-170.

Celec, P. 2004. Nuclear factor kappa B-molecular biomedicine: the next generation. Biomedicine \& Pharmacotherapy 58(67): $365-371$.

Cinar, Y., Senyol, A.M. \& Duman, K. 2001. Blood viscosity and blood pressure: Role of temperature and hyperglycemia. American Journal of Hypertension 14(5 Pt 1): 433-438.

Eckerson, H.W., Wyte, C.M. \& La Du, B.N. 1983. The human serum paraoxonase/arylesterase polymorphism. American Journal of Human Genetics 35(6): 1126-1138.

Erel, O. 2005. A new automated colorimetric method for measuring total oxidant status. Clinical Biochemistry 38(12): $1103-1111$.

Erel, O. 2004. A novel automated method to measure total antioxidant response against potent free radical reactions. Clinical Biochemistry 37(2): 112-119.

Fernández-Arroyo, S., Camps, J., Menendez, J.A. \& Joven, J. 2015. Managing hypertension by polyphenols. Planta Medica 81(8): 624-629.

Ferrannini, E. \& Cushman, W.C. 2012. Diabetes and hypertension: The bad companions. The Lancet 380(9841): 601-610.

Gogebakan, A., Talas, Z.S., Ozdemir, I. \& Sahna, E. 2012. Role of propolis on tyrosine hydroxylase activity and blood pressure in nitric oxide synthase-inhibited hypertensive rats. Clinical and Experimental Hypertension 34(6): 424-428.

González, F.E.M., Ponce-RuÍz, N., Rojas-GarcÍa, A.E., BernalHernández, Y.Y., Mackness, M., Ponce-Gallegos, J., Cardoso-Saldaña, G., Jorge-Galarza, E., Torres-Tamayo, M. \& Medina-Díaz, I.M. 2019. PON1 concentration and high-density lipoprotein characteristics as cardiovascular biomarkers. Archives of Medical Sciences. Atherosclerotic Diseases 4: e47-54

Granér, M., James, R.W., Kahri, J., Nieminen, M.S., Syvänne, M. \& Taskinen, M.R. 2006. Association of paraoxonase-1 activity and concentration with angiographic severity and extent of coronary artery disease. Journal of the American College of Cardiology 47(12): 2429-2435.

Gur, M., Aslan, M., Yildiz, A., Demirbag, R., Yilmaz, R., Selek, S., Erel, O. \& Ozdogru, I. 2006. Paraoxonase and arylesterase activities in coronary artery disease. European Journal of Clinical Investigation 36(11): 779-787.
Harrison, D.G., Gongora, M.C., Guzik, T.J. \& Widder, J. 2007. Oxidative stress and hypertension. Journal of the American Society of Hypertension: JASH 1(1): 30-44.

Horowitz, J.D. \& Heresztyn, T. 2007. An overview of plasma concentrations of asymmetric dimethylarginine (ADMA) in health and disease and in clinical studies: Methodological considerations. Journal of Chromatography B 851(1-2): 42-50.

John, S., Delles, C., Jacobi, J., Schlaich, M.P., Schneider, M., Schmitz, G. \& Schmieder, R.E. 2001. Rapid improvement of nitric oxide bioavailability after lipid-lowering therapy with cerivastatin within two weeks. Journal of the American College of Cardiology 37(5): 1351-1358.

Kaliora, A.C., Dedoussis, G.V. \& Schmidt, H. 2006. Dietary antioxidants in preventing atherogenesis. Atherosclerosis 187(1): 1-17.

Kanbur, M., Eraslan, G. \& Silici, S. 2009. Antioxidant effect of propolis against exposure to propetamphos in rats. Ecotoxicology and Environmental Safety 72(3): 909915.

Kolankaya, D., Selmanoğlu, G., Sorkun, K. \& Salih, B. 2002. Protective effects of Turkish propolis on alcoholinduced serum lipid changes and liver injury in male rats. Food Chemistry 78(2): 213-217.

Kosecik, M., Erel, O., Sevinc, E. \& Selek, S. 2005. Increased oxidative stress in children exposed to passive smoking. International Journal of Cardiology 100(1): 61-64.

Kubota, Y., Umegaki, K., Kobayashi, K., Tanaka, N., Kagota, S., Nakamura, K., Kunitomo, M. \& Shinozuka, K. 2004. Anti-hypertensive effects of Brazilian propolis in spontaneously hypertensive rats. Clinical and Experimental Pharmacology and Physiology 31: S29-S30.

Leo, M.D., Kandasamy, K., Subramani, J., Tandan, S.K. \& Kumar, D. 2015. Involvement of inducible nitric oxide synthase and dimethyl arginine dimethylaminohydrolase in $\mathrm{N} \omega$-nitro-L-arginine methyl ester (L-NAME)-induced hypertension. Cardiovascular Pathology 24(1): 49-55.

Mackness, B., McElduff, P. \& Mackness, M.I. 2005. The paraoxonase-2-310 polymorphism is associated with the presence of microvascular complications in diabetes mellitus. Journal of Internal Medicine 258(4): 363-368.

Mackness, M. \& Mackness, B. 2015. Human paraoxonase-1 (PON1): Gene structure and expression, promiscuous activities and multiple physiological roles. Gene 567(1): 12-21.

Madamanchi, N.R. \& Runge, M.S. 2013. Redox signaling in cardiovascular health and disease. Free Radical Biology \& Medicine 61: 473-501.

Mărghitas, L.A., Stanciu, O.G., Dezmirean, D.S., Bobiș, O., Popescu, O., Bogdanov, S. \& Campos, M.G. 2009. In vitro antioxidant capacity of honeybee-collected pollen of selected floral origin harvested from Romania. Food Chemistry 115(3): 878-883.

Maruyama, H., Sumitou, Y., Sakamoto, T., Araki, Y. \& Hara, H. 2009. Antihypertensive effects of flavonoids isolated from 
brazilian green propolis in spontaneously hypertensive rats. Biological \& Pharmaceutical Bulletin 32(7): 12441250.

Mishima, S., Yoshida, C., Akino, S. \& Sakamoto, T. 2005. Antihypertensive effects of Brazilian propolis: Identification of caffeoylquinic acids as constituents involved in the hypotension in spontaneously hypertensive rats. Biological \& Pharmaceutical Bulletin 28(10): 1909-1914.

Mohammadzadeh, S., Shariatpanahi, M., Hamedi, M., Ahmadkhaniha, M., Samadi, R. \& Ostad, S.N. 2007. Chemical composition, oral toxicity and antimicrobial activity of Iranian propolis. Food Chemistry 103: 1097-1103.

Nguelefack, T.B., Mekhfi, H., Dongmo, A.B., Dimo, T., Watcho, P., Zoheir, J., Legssyer, A., Kamanyi, A. \& Ziyyat, A. 2009. Hypertensive effects of oral administration of the aqueous extract of Solanum torvum fruits in L-NAME treated rats: Evidence from in vivo and in vitro studies. Journal of Ethnopharmacology 124(3): 592-599.

Ogeturk, M., Kus, I., Colakoglu, N., Zararsiz, I., Ilhan, N. \& Sarsilmaz, M. 2005. Caffeic acid phenethyl ester protects kidneys against carbon tetrachloride toxicity in rats. Journal of Ethnopharmacology 97(2): 273-280.

Okutan, H., Ozcelik, N., Yilmaz, H.R. \& Uz, E. 2005. Effects of caffeic acid phenethyl ester on lipid peroxidation and antioxidant enzymes in diabetic rat heart. Clinical Biochemistry 38(2): 191-196.

Palm, F., Onozato, M.L., Luo, Z. \& Wilcox, C.S. 2007. Dimethylarginine dimethylaminohydrolase (DDAH): Expression, regulation, and function in the cardiovascular and renal systems. American Journal of Physiology-Heart and Circulatory Physiology 293(6): H3227-H3245.

Palmer, R.M., Ferrige, A.G. \& Moncada, S. 1987. Nitric oxide release accounts for the biological activity of endothelium-derived relaxing factor. Nature 327(6122): 524-526.

Parlakpinar, H., Sahna, E., Acet, A., Mizrak, B. \& Polat, A. 2005. Protective effect of caffeic acid phenethyl ester (CAPE) on myocardial ischemia-reperfusion-induced apoptotic cell death. Toxicology 209(1): 1-14.

Pasqualini, L., Cortese, C., Marchesi, S., Siepi, D., Pirro, M., Vaudo, G., Liberatoscioli, L., Gnasso, A., Schillaci, G. \& Mannarino, E. 2005. Paraoxonase-1 activity modulates endothelial function in patients with peripheral arterial disease. Atherosclerosis 183(2): 349-354.

Pérez-Méndez, Ó., Pacheco, H.G., Martínez-Sánchez, C. \& Franco, M. 2014. HDL-cholesterol in coronary artery disease risk: Function or structure? Clinica Chimica Acta 429: 111-122.

Prytzyk, E., Dantas, A.P., Salomão, K., Pereira, A.S., Bankova, V.S., De Castro, S.L. \& Neto, F.R. 2003. Flavonoids and trypanocidal activity of Bulgarian propolis. Journal of Ethnopharmacology 88(2-3): 189-193.

Robbesyn, F., Salvayre, R. \& Negre-Salvayre, A. 2004. Dual role of oxidized LDL on the NF-kappaB signaling pathway. Free Radical Research 38(6): 541-551.
Rozenberg, O., Shiner, M., Aviram, M. \& Hayek, T. 2008. Paraoxonase 1 (PON1) attenuates diabetes development in mice through its antioxidative properties. Free Radical Biology \& Medicine 44(11): 1951-1959.

Ryu, S.Y., Oh, K.S., Kim, Y.S. \& Lee, B.H. 2008 Antihypertensive, vasorelaxant and inotropic effects of an ethanolic extract of the roots of Saururus chinensis. Journal of Ethnopharmacology 118(2): 284-289.

Salmas, R.E., Gulhan, M.F., Durdagi, S., Sahna, E., Abdullah, H.I. \& Selamoglu, Z. 2017. Effects of propolis, caffeic acid phenethyl ester, and pollen on renal injury in hypertensive rat: An experimental and theoretical approach. Cell Biochemistry and Function 35(6): 304-314.

Sato, S., Mukai, Y., Yamate, J., Kato, J., Kurasaki, M., Hatai, A. \& Sagai, M. 2008. Effect of polyphenol-containing azuki bean (Vigna angularis) extract on blood pressure elevation and macrophage infiltration in the heart and kidney of spontaneously hypertensive rats. Clinical and Experimental Pharmacology \& Physiology 35(1): 43-49.

Selamoglu, Z.S., Ozdemir, I., Ciftci, O., Gulhan, M.F. \& Savci, A. 2015. Antioxidant effect of eThanolic extract of propolis in liver of L-NAME treated rats. Advances in Clinical and Experimental Medicine 24(2): 227-232.

Selek, S., Cosar, N., Kocyigit, A., Erel, O., Aksoy, N., Gencer, M., Gunak, F. \& Aslan, M. 2008. PON1 activity and total oxidant status in patients with active pulmonary tuberculosis. Clinical Biochemistry 41(3): 140-144.

Selek, S., Aslan, M., Horoz, M., Gur, M. \& Erel, O. 2007. Oxidative status and serum PON1 activity in beta-thalassemia minor. Clinical Biochemistry 40(5-6): 287-291.

Simão, S., Gomes, P., Pinto, V., Silva, E., Amaral, J.S., Igreja, B., Afonso, J., Serrão, M.P., Pinho, M.J. \& Soares-da-Silva, P. 2011. Age-related changes in renal expression of oxidant and antioxidant enzymes and oxidative stress markers in male SHR and WKY rats. Experimental Gerontology 46(6): 468-474.

Simko, F., Matuskova, J., Luptak, I., Krajcirovicova, K., Kucharska, J., Gvozdjakova, A., Babal, P. \& Pechanova, O. 2004. Effect of simvastatin on remodeling of the left ventricle and aorta in L-NAME-induced hypertension. Life Sciences 74(10): 1211-1224.

Talas, Z.S. 2014. Propolis reduces oxidative stress in 1-NAMEinduced hypertension rats. Cell Biochemistry and Function 32(2): 150-154.

Talas, Z.S. \& Gulhan, M.F. 2009. Effects of various propolis concentrations on biochemical and hematological parameters of rainbow trout (Oncorhynchus mykiss). Ecotoxicology and Environmental Safety 72(7): 1994-1998.

Talas, Z.S., Ozdemir, I., Ciftci, O., Cakir, O., Gulhan, M.F. \& Pasaoglu, O.M. 2014. Role of propolis on biochemical parameters in kidney and heart tissues against L-NAME induced oxidative injury in rats. Clinical and Experimental Hypertension 36(7): 492-496.

Talas, Z.S., Gogebakan, A. \& Orun, I. 2013. Effects of propolis on blood biochemical and hematological parameters 
in nitric oxide synthase inhibited rats by $\mathrm{N} \omega$-Nitro-Larginine methyl ester. Pakistan Journal of Pharmaceutical Sciences 26(5): 915-919.

Taner, A., Unlu, A., Kayrak, M., Tekinalp, M., Ayhan, S.S., Arıbaş, A. \& Erdem, S.S. 2013. The value of serum asymmetric dimethylarginine levels for the determination of masked hypertension in patients with diabetes mellitus. Atherosclerosis 228(2): 432-437.

Vasa, M., Fichtlscherer, S., Adler, K., Aicher, A., Martin, H., Zeiher, A.M. \& Dimmeler, S. 2001. Increase in circulating endothelial progenitor cells by statin therapy in patients with stable coronary artery disease. Circulation 103(24): 2885-2890.

Wilma, D.S.C. 2011. Evaluation of effect of smoking and hypertension on serum lipid profile and oxidative stress. Asian Pacific Journal of Tropical Disease 1(4): 289-291.

Xu, J., Fan, G., Chen, S., Wu, Y., Xu, X.M. \& Hsu, C.Y. 1998. Methylprednisolone inhibition of TNF-alpha expression and NF-kB activation after spinal cord injury in rats. Molecular Brain Research 59(2): 135-142.

Zheng, J.P., Zhang, Y., Edvinsson, L., Hjalt, T. \& Xu, C.B. 2010. NF-kappaB signaling mediates vascular smooth muscle endothelin type B receptor expression in resistance arteries. European Journal of Pharmacology 637(1-3): 148-154.

Mehmet Fuat Gulhan

Department of Medicinal and Aromatic Plants

Vocational School of Technical Sciences

Aksaray University, Aksaray

Turkey
Betul Ozdemir*

Department of Cardiology

Faculty of Medicine

Nigde Ömer Halisdemir University

Campus, Nigde

Turkey

Zeliha Selamoglu

Department of Medical Biology

Faculty of Medicine

Nigde Ömer Halisdemir University

Campus, Nigde

Turkey

Engin Sahna

Department of Pharmacology

Faculty of Medicine

Firat University, Elazig

Turkey

*Corresponding author; email: betulozaltun@ohu.edu.tr

Received: 7 August 2020

Accepted: 30 November 2020 